\title{
Handling learner discipline problems: A psycho-social whole school approach
}

\begin{tabular}{|c|c|}
\hline \multicolumn{2}{|c|}{$\begin{array}{l}\text { Authors: } \\
\text { Elias E. Kourkoutas }{ }^{1} \\
\text { Charl C. Wolhuter }^{2}\end{array}$} \\
\hline \multicolumn{2}{|c|}{$\begin{array}{l}\text { Affiliations: } \\
{ }^{1} \text { Department of Psychology, } \\
\text { University of Crete, Greece }\end{array}$} \\
\hline \multicolumn{2}{|c|}{$\begin{array}{l}{ }^{2} \text { School of Education, } \\
\text { North-West University, } \\
\text { Potchefstroom Campus, } \\
\text { South Africa }\end{array}$} \\
\hline \multicolumn{2}{|c|}{$\begin{array}{l}\text { Correspondence to: } \\
\text { Charl Wolhuter }\end{array}$} \\
\hline \multicolumn{2}{|c|}{$\begin{array}{l}\text { Email: } \\
\text { charl.wolhuter@nwu.ac.za }\end{array}$} \\
\hline \multicolumn{2}{|c|}{$\begin{array}{l}\text { Postal address: } \\
\text { Private Bag X6001, } \\
\text { Potchefstroom 2520, } \\
\text { South Africa }\end{array}$} \\
\hline \multirow{2}{*}{\multicolumn{2}{|c|}{$\begin{array}{l}\text { Dates: } \\
\text { Received: } 07 \text { Jan. } 2013 \\
\text { Accepted: } 28 \text { Oct. } 2013 \\
\text { Published: } 09 \text { Dec. } 2013 \\
\text { How to cite this article: } \\
\text { Kourkoutas, E.E. \& Wolhuter, } \\
\text { C.C., 2013, 'Handling learner } \\
\text { discipline problems: A } \\
\text { psycho-social whole school } \\
\text { approach', Koers - Bulletin } \\
\text { for Christian Scholarship } \\
\text { 78(3), Art. \#550, } 8 \text { pages. } \\
\text { http://dx.doi.org/10.4102/ } \\
\text { koers.v78i3.550 }\end{array}$}} \\
\hline & \\
\hline \multicolumn{2}{|c|}{$\begin{array}{l}\text { Copyright: } \\
\text { (C) 2013. The Authors. } \\
\text { Licensee: AOSIS } \\
\text { OpenJournals. This work } \\
\text { is licensed under the } \\
\text { Creative Commons } \\
\text { Attribution License. }\end{array}$} \\
\hline \multicolumn{2}{|l|}{ Read online: } \\
\hline 回的回 & $\begin{array}{l}\text { Scan this QR } \\
\text { code with your } \\
\text { smart phone or } \\
\text { mobile device } \\
\text { to read online. }\end{array}$ \\
\hline
\end{tabular}

Learner discipline is a problem in South African schools. The most serious aspect is addressing learner-discipline problems. Research has shown that teachers are at a loss for effective methods for maintaining discipline. The literature that does exist pertaining to methods of maintaining discipline, invariably enumerates a host of techniques in a 'bag of tricks' fashion: behaviouristic, like treating symptoms, that is, the behavioural manifestation rather than addressing the causes of that behaviour, paying no attention to the psychic dynamics and social context behind poor discipline. This is at variance with the fact that learner-discipline problems have a causal base which reaches far beyond the individual teacher-individual learner interaction. At the levels of the school, family and society, as well as at the level of the spiritual and social functioning of the child and how that might result in discipline problems, and how that should be taken into account when addressing learner discipline problems, a host of literature has been published in recent years. This article surveys this literature, synthesising it in a systematic way that shows a broader and more extensive way of approaching the issue of the problems of addressing learner discipline in South African schools. Although the problem of ill discipline in schools is not limited to or absent from schools that educate on biblical principles, the discussion in the literature occasionally ventures into a brief mention of how the problem could be approached from a holistic and integrated Christian perspective.

Die hantering van leerderdissiplineprobleme: 'n Psigo-sosiale geheelskoolbenadering. Leerderdissipline in Suid-Afrikaanse skole is 'n probleem. Die mees problematiese aspek is die hantering van dié probleme. Navorsing het aangetoon dat onderwysers nie oor doeltreffende metodes om leerderdissipline te handhaaf beskik nie. Literatuur oor dissiplinehandhawingsmetodes wat wel bestaan lys 'n reeks tegnieke, in 'n behaviouristiese paradigma, wat die simptome eerder as die oorsake van die probleem aanspreek, en wat nie die psigiese dinamika en sosiale konteks van leerderdissiplineprobleme erken nie. Dit rym nie met die feit dat leerderdissipline ' $n$ oorsaaklike basis het wat veel verder as die individuele onderwyser-individuele leerder interaksie strek nie. Op die vlakke van die skool, die gesin en die samelewing, sowel as die spirituele en sosiale funksionering van die kind en hoe al hierdie faktore in dissiplineprobleme kan uitloop en in berekening gebring behoort te word wanneer dit by die aanspreek van leerderdissiplineprobleme kom, is ' $n$ magdom literatuur die afgelope aantal jare gepubliseer. Hierdie artikel bied 'n oorsig van dié literatuur en dui so 'n meer omvattende benadering aan om leerderdissiplineprobleme in Suid-Afrikaanse skole te hanteer. Ofskoon die probleem van leerderdissiplineprobleme nie beperk is of afwesig is van skole wat onderwys op 'n Bybelse grondslag verskaf nie, word die bespreking van die literatuuroorsig voorsien van 'n Christelike lewensopvatlike bobou.

\section{Statement of problem}

Learner discipline is a problem in South African schools (Wolhuter \& Van Staden 2008). Judging from the international literature, this problem is not limited to South Africa, but is a worldwide phenomenon (Steyn et al. 2003). Research on learner discipline problems in South African schools has revealed that the biggest problem is how to handle them (Wolhuter \& Van Staden 2008). Teachers are at a loss as to how to deal with ill discipline. Furthermore, the research that has been done on the handling of learner-discipline problems focuses almost exclusively on the single teacher's methods of maintaining discipline (e.g. Biemond, Van der Walt \& Wolhuter 2010; Oosthuizen, Wolhuter \& Du Toit 2003; Van der Walt, Potgieter \& Wolhuter 2010; Wolhuter \& Van Staden 2009) - the sole exception being the study by Van der Westhuizen, Oosthuizen and Wolhuter (2008) on the use of organisational culture in schools to create a school environment conducive to disciplined learners. The second problem is that this literature on methods of maintaining discipline cites a host of techniques in a 'bag of tricks' fashion: behaviouristic, like treating symptoms, that is, the bad behaviour, rather than addressing the causes of such 
behaviour, paying no attention to the psychic and social dynamics behind the behavioural manifestation of poor discipline. This is at variance with the fact that learnerdiscipline problems have a causal base which reaches much deeper than the behavioural symptoms of poor discipline. Regarding the design of strategies to be implemented in schools, many questions are raised by contemporary research concerning the way policy makers or even researchers and clinicians decide upon the type of intervention for children with discipline problems. Wherever the medical or behaviouristic approach is still dominant, interventions usually do not sufficiently consider ecological variables and complex interactional processes that take place within the school system and contribute to the development of the disorder. Unavoidably, this behaviouristic theoretical stance leads to a wrong or even counter-productive intervention (Schmidt Neven 2010).

\section{Aim of research}

At the levels of the school, family and society, as well as the psychic and social functioning of the child and how that might result in poor discipline, a host of literature has been published in recent years. The aim of this article is to survey this literature and to build a framework for a school-familysociety approach to creating classrooms characterised by disciplined learners, taking into account the learner's psychic functioning and social context when working out a plan to address discipline problems. As such, it is an attempt to address, first, the lacuna in scholarly literature on learner discipline, namely the reductionistic view that learnerdiscipline problems are behavioural problems only, or at best can be ascribed to one set of factors, for example, teacherlearner relations, or the organisational culture of the school. This article represents an attempt to offer a more holistic, integrated view of learner discipline problems and the causes behind the behavioural manifestations of them. This view then includes and brings together under one umbrella the child's personal history and intrapsychic life or dynamics, the quality of the family relationship, the teacher's attitude and teaching style, the organisational and social characteristics of the school, and the nature of society.

\section{Research methodology}

The research method followed was that of a literature survey, employing the major databases in the educational, behavioural and social sciences, namely ERIC, Google Scholar and PsyInfo. Keywords used were: (1) behavioural and conduct problems, (2) childhood, (3) teacher's attitude and (4) ecosystemic approach. The notion of 'discipline' was deliberately eschewed because, in the first place, as used in this article and in South Africa, the term has no global currency (with the exception of the United Kingdom) and, secondly, as stated above, where it is used with similar meaning, as in this article, scholars tend to limit it to behavioural manifestations, and the handling of discipline problems to behavioural management. The time period used for the search was from 2005-2012. This produced a total of 280 scholarly sources which were studied. This body of literature was studied with a view to finding the literature relevant to learner-discipline problems, their causes, and ways to address them.

\section{Findings}

\section{Principles when studying children's discipline problems and when designing classroom- and schoolwide interventions}

Based on extended empirical and clinical evidence, the following principles are essential when we study children's discipline problems in schools in order to design comprehensive or effective classroom- or schoolwide interventions:

- As explained above, children's discipline problems may be, as explained above, the outcome of a variety of causes (personal/familial/school/social), with varying degrees of severity and weight. For example, an acceptably provocative or immature, defiant behaviour may be related to a child who has not adequately internalised necessary limits, who feels extremely frustrated, as she or he is unable to adequately respond to school requirements or attain the acceptance of his or her teacher and peers with acceptable behaviour; a similar aggressive, provocative or defiant behaviour might, in contrast, be linked to a serious family problem, maltreatment, or physical or emotional abuse; in other cases, aggressive or problematic and disruptive behaviours may be linked to a lack of necessary psycho-social skills or to the child's immaturity, due in turn to a variety of family or other factors.

- Recurring instances of poor discipline within school settings, particularly in their more severe and persistent forms, are typically characterised as the product of stressful environments (such as abuse or severe or harsh rearing and punishment practices), poor internal regulation, and undeveloped relational abilities and perceptions (Dishon \& Patterson 2006).

- In many cases, students' discipline problems are perceived by teachers as: purposefully oppositional-that is, based on a supposed wish to upset others and maintain a one-up position on them - rather than as a manifestation of the child's unhappiness and inner difficulties.

- Attempts to eliminate discipline problems that represent an essential, nonverbal form of communication may contribute to a poor outcome as these are likely to result in a depressed, frustrated, and resentful child.

- It is critical that adults attempt to understand the meaning of the targeted behaviours from the child's perspective before implementing an intervention (Kourkoutas 2012).

- Whilst some mild learner-discipline problems may be related to a broader pattern of behavioural and emotional problems, most of them do not necessarily represent a serious and persistent emotional disorder or require a psychiatric diagnosis (Kourkoutas 2012).

- A formal descriptive assessment of a child's problematic behaviour based on a psychiatric model of thinking in most cases is insufficient to ensure a thorough 
understanding of the necessary intervention model/ programme/practices to be implemented/employed.

- A systemic and psychosocially sensitive approach and reflection are often necessary in order to obtain insight in the intrapsychic reality of the child and reveal the wide range of factors (e.g. intra/interpersonal, relational, academic or family) that should be treated or faced.

- A multisource evaluation is also necessary in order to ensure a comprehensive approach to the complex contextual reality in which the child functions and behaves, as well as the way significant people in his or her life perceive and deal with his or her discipline problems as they are manifest. This should be based upon a thorough knowledge of the family dynamics and background- essential for both teachers and educational psychologists who are intended to intervene.

- Inclusive school and educational psychologists' practice should be based on a different ethos from the one expressed by a strictly punitive and discipline-oriented logic.

- In addition, an inclusive school approach should focus on strengthening the problematic children's inherent capacities or potential (see Kourkoutas 2012).

\section{First step in an intervention strategy: Identifying children with discipline problems and gaining a comprehensive understanding}

Classroom educational and/or professional intervention efforts should be based on or grounded in a comprehensive understanding of the child's social and academic skills and deficits, his or her family and school background, their previous classroom experiences, and the nature of relational patterns and social relationships. This requires significant data-collection effort across a range of constructs and the child's life levels or domains.

Empirical studies have shown that in some particular groups of children, school difficulties can generate feelings of disappointment, inferiority, anger and aggression which, coupled with other risk factors, may cause discipline problems (Kourkoutas 2012; Mash \& Wolfe 2010; Maughan 2001; Roeser \& Eccles 2000). In any case, school failure might be an important predictor of the early onset of discipline problems (Kourkoutas 2012; Mash \& Wolfe 2010).

Early rejection by teachers and peers is a risk factor for the early, or later, onset of discipline problems. Researchers who have focused on 'disruptions' in childhood suggest that these behaviours can escalate into increasingly hostile teacherstudent interactions, either covert or overt (Bloomquist \& Schnell 2002; Campbell 2002; Kourkoutas 2012; McMahon \& Forehand 2003). In some extreme cases, conflictual relationships with teachers may be quite traumatic, leading the child to exaggerated disruptive reactions. Accordingly, teachers may also experience their relationship with these students or their families as being very distressing (Kourkoutas 2012; Kourkoutas, Georgiadi \& Hadzaki 2011). It has in fact been shown that 'aggressive children' tend to induce hostile, confusing or ambivalent emotions in others and receive aggressive, aversive or inappropriate responses from their teachers (Blanchard, Casagrance \& McCulloch 1994; Dodge 2000; Kauffman 2001; Mash \& Wolfe 2010; Roeser \& Eccles 2000).

In a holistic or ecosystemic (encompassing school, family and society) and psychodynamic model, discipline problems in childhood are regarded as the result of a problematic relationship between the child as an evolving system and (proximal or distal) environmental systems such as the parental couple, family, siblings, classmates, neighbourhood, school system, peers, social institutions and society (Henggeler et al. 1998; Kourkoutas 2012; Munger, Donkervoet \& Morse 1998; Sneider, Reid \& Patterson 2003). This relationship is affected by the dialectic action of multiple endogenous and exogenous factors (Fraser 2004; Pianta 2006). As family and child are dynamic, evolving systems continuously interacting with other systems, a multitude of pathways to deal with problems and a multitude of types and forms of antisocial and aggressive behaviours associated with a series of emotional, relational, and personality disorders are possible (Boxer \& Frick 2008; Dodge \& Pettit 2003; Fraser, Kirby \& Smolowski 2004; Frick 2006). Overall, the problematic developmental outcomes (i.e., discipline problems) result from a variety of different risk factors that can operate at multiple levels of influence (Boxer \& Frick 2008).

Once children with learner discipline problems have been identified, and the full extent of these problems, including their causal antecedents in the intrapsychic life of the child, school factors, family-related factors and society-related factors have been mapped and assessed, an intervention strategy can be planned.

\section{Levels of positive-based psycho-social intervention}

Schools are dynamic, multi-dimensional, and multi-level settings for development (Pianta 2006).

Positive school-based interventions could be addressed at the following levels:

- Universal school support (Kourkoutas 2012; Kourkoutas \& Raul Xavier 2010): All students must be taught the schoolwide rules and expectations; learn to work from a collaborative or partnership perspective; be encouraged to express their needs and difficulties; verbalise their interpersonal and/or even intrapersonal problems in a trusting climate; express their ideas / beliefs/perceptions / thoughts in a context free of fear; be sensitised to children with difficulties or exceptionalities; develop their social and academic skills or problem-solving skills; learn to trust one another in a supportive environment and therefore develop their self-competence and self-confidence. In addition, teachers should have proactive classroom management procedures in place and be adequately trained or prepared to use counselling or prosocial skills and alternative educational methods in order to establish a positive classroom dynamic, enhance their students' 
abilities and ensure the elementary management of mild frictions or classroom or individual disruptions.

- Individualised student interventions: Students with serious problem behaviour must receive intensive, individualised support or treatment accompanied by teacher and family counselling, if possible.

\section{Principles for intervention at the school level}

In order for interventions to be effective, a series of basic principles should guide practitioners in the design of school-based psychosocial interventions. More specifically, preventive or intervention programmes which attempt to foster the social-emotional competencies of children at-risk for or with manifested behaviour problems should consider the following principles:

- Schools should be open to modifications of their organisational and inclusive philosophy, teaching theory and educational methods in order to provide an educative home for children with the whole range of problems.

- Multi-year, multi-component interventions are more effective than single-component, short-term programmes.

- Efforts at promoting competence and health are best begun before signs of risky behaviours emerge and should continue throughout adolescence.

- Programming that has multiple elements involving family, school and community is more likely to be successful than efforts aimed at a single domain (see Brehm \& Doll 2009; Dettmer, Thurston \& Dyck 2005; Dinkmeyer Jr \& Carlson 2006; Greenberg et al. 2003; Hatzichristou et al. 2010; Kourkoutas 2012; Nastasi, Moore \& Varjas 2004; Ross, Powell \& Elias 2004; Weare \& Gray 2003).

Whole school interventions may not be adequate, and some instances may require individualised student interventions to address discipline problems. Teachers must be aware that children with oppositional, disruptive, aggressive, or antisocial behaviour do not constitute a homogeneous group with common characteristics. On the contrary, each child has its own particular dynamic (both psychological and behavioural) and each child typically requires a special approach and understanding of the underlying problems and functioning.

\section{Individualised learner interventions}

- A resilient classroom and skilful, well-supported teachers should foster supportive relationships even with the most troubled students. A positive relationship with a supportive teacher in combination with an early, specialised intervention before the children's pathological defence and coping mechanisms become reinforced and crystallised reduces the risk for the child to enter into an endless cycle of mutual rejection within the school environment (Fell 2002; Salend 2004; Urquhart 2009; Weare 2000). Therefore, it is urgent for schools to have in place an inclusive policy and curricula that link emotional development and teaching skills with learning and teaching processes. Furthermore, schools should be responsible for creating a caring environment to foster students' inner potentials and competencies as well as to contain their emotional and behavioural disruptions (Kourkoutas 2012; Kourkoutas \& Raul Xavier 2010; Urquhart 2009; Ysseldyke \& Algozzine 2006). For this environment to be realised, it is necessary to have teachers who are well-trained, committed and willing to collaborate with school psychologists and other professionals, such as school social workers. It seems that teachers who are adequately trained and supported by long-term interdisciplinary teams become more competent. When teachers are adequately trained and coached, they are able to manage their students' discipline problems within the classroom and thus avoid referring them to external settings (Miller 2003; Nastasi, Moore \& Varjas 2004; Ysseldyke \& Algozzine 2006). In order to enhance the attainment and the social integration of all vulnerable or emotionally and behaviourally disturbed children, the following principles which should be present in the design of interventions have been identified by research:

- Careful individual monitoring.

- Flexible grouping.

- Customising strategies to individual circumstances.

- Strategies that promote partnership among all involved practitioners.

- A focus on the academic as well as the social and emotional processes of students at risk.

- Teachers and professionals committed to helping and supporting pupils with difficulties (e.g. wanting to 'do the best' for all children) (Lunt \& Norwich 2009:99).

- Promoting a learning achievement and performance together with emotional well-being.

- Promoting an inclusive ethos within the school unit. In devising strategies to address learner discipline problems in schools, both at school and at the individual learner level, the teacher therefore occupies a pivotal position (see Ainscow et al. 2006; Kourkoutas 2008; Lunt \& Norwich 2009:99; McEvoy \& Welker 2000; Weare 2000; Ysseldyke \& Algozzine 2006).

\section{The teacher and learner discipline problems, and addressing such problems}

Summarising the outcome of research, we conclude that the following principles concerning teacher behaviour may play a decisive role in minimising the commencement of learner discipline problems, and in maximising the efficacy of strategies designed to address such problems (see Fraser et al. 2004; Young, Marchant \& Wilder 2004; Richman, Bowen \& Wooley 2004): (1) teachers need to establish clear rules and boundaries, whilst at the same time recognising that they might be unable to realise their expectations regarding the desired behaviour and performance of children at school (Kauffman 2001; Walker, Colvin \& Ramsey 1995; Young et al. 2004); (2) teachers should guard against inconsistent or unrealistic expectations about the children's abilities. These may stem from the stereotypical or distorted perceptions of the teacher, the negative behaviours of the child, the information the teacher gets from her or his colleagues, or even the results of a special diagnosis concerning the child 
(Kauffman 2001; Young et al. 2004); (3) teachers need to adapt their responses to the special needs of children (Kauffman 2001; Young et al. 2004); (4) likewise, teachers should avoid a rigid stereotypical and unidimensional attitude towards students and their problems; for instance, inconsistent and contradictory techniques used to manage behaviour problems (Bloomquist \& Schnell 2002; Kauffman 2001; Young et al. 2004); and (5) teachers should guard against failure to provide the child with an appropriate educational setting. This could include giving unclear instructions, a poor or restricted curriculum, not focusing on psychosocial skills development, repulsive school activities, ineffective and outdated instructional strategies, failure to foster students' creative and critical skills, extreme emphasis on the learning nature of education, a school focused on a stereotypical learning environment, and unpleasant or inappropriate facilities.

\section{Synthesis: Pre-theoretical and theoretical perspectives on the problem}

The above overview of research regarding the problem with discipline in schools shows that the problem is indeed a serious one but also that there are a variety of ways in which the problem could be addressed. In the overview, the emphasis was constantly on the necessity for a holistic and extensive approach to efforts to address the problem. Although the research review was necessary for gaining insight into the various ramifications of the problem, it was not adequate; it was little more than a mere catalogue of research findings. This catalogue of findings should be placed in a deeper pre-theoretical and theoretical perspective for them to cast more light on the problem (Van der Walt \& Potgieter 2012:221), and that is what will be done tentatively in the rest of this particular section.

The overview of research results revealed, firstly, that the most suitable approach to the discipline problem in schools would be a holistic, integrated, comprehensive and total one in which the entire spectrum of factors involved would be addressed (Wright 2010:133). The approach should be based on many sources of information about all the role players involved in a particular incident or situation; all the factors and conditions involved (see the discussion of societal relationships below) should be taken into consideration. Any effort to eradicate the problem of indiscipline should be based on an inclusive policy. As the survey showed, the approach should be 'meaningful and responsible'. In view of this brief summary it can be deduced that the very first task of the educationist confronted with the discipline problem should be to find a solid philosophical and life- and worldview foundation for deciding what would count as a meaningful and responsible interpretation of the notion: 'an integrated and holistic approach to the problem' (see Olthuis 2012:passim; Lategan 2010:152-153; Peck 2006:33; Weideman 2010:159). Should the problem be approached on the basis of, for instance, a biblical life- and worldview or on the basis of some other worldview? If, for instance, the problem is approached from a biblical lifeview perspective, the educationist would approach the problem from the biblical interpretation of the term 'discipline', namely 'discipleship'. The educator will do her or his utmost to guide, equip and enable the child to become a follower, that is, a disciple, of the example set by the educator, who in her or his heart will be a follower of Jesus Christ and His teachings delivered, for instance, during the Sermon on the Mount (Mt 5). By emulating the example set by the educator, the child will ideally also become a follower of Jesus Christ.

The overview of research results showed, in the second place, that the educationist faced with a discipline problem should possess his or her own anthropology or view regarding the human being (Van der Walt \& Potgieter 2012:225-226). The results detailed above abound with expressions such as: 'psychic dynamics', 'personal intervention', the 'child's personal history', 'intra- and inter-psychical factors and reality', 'emotions and feelings', a 'purposely oppositional attitude', aggression, 'disruption of feedback loops', 'internal distress and pain', 'unbearable feelings', 'multiple endogenous and exogenous factors', 'multiple levels of influence', 'a variety of risk factors, individual treatment', 'psycho-social interventions', an individualised approach, and so forth. All of these factors pertain in some or other way to the nature and state of the human being. Again, as in the case of the first perspective, space constraints do not allow a detailed exposition of a particular view of the human being, or anthropology, on which an approach for addressing the discipline problem should be based. Suffice it to say that the educationist has, also in this case, to decide whether to approach the problem according to a biblical view of the human being or according to some other anthropological perspective (Julian 2002:112). If, for instance, the educator decides to base her or his interventions against indiscipline in the classroom on a biblical anthropology, she or he would tend to see the child as the image of God, as the crown of creation, a person charged with what has become known as the 'cultural commission' or 'cultural mandate', that is, God's command on the culmination of his work in creation. Though God considers creation itself to be 'very good', he turns the task of exploring and developing its powers and potentialities, the task of building a civilization, over to his image bearers (Colson \& Pearson 2001:20). Our calling, as Colson and Pearson (2001:xii) correctly observe, is not only to order our own lives by divine principles but also to engage the world. We are to fulfil both the great commandment and the cultural commission, which means that we are commanded both to preach the 'good news' and to bring all things into submission to God's order, by defending and living out God's truth in the unique historical and cultural conditions of our age. The same applies, in the third place, to the next perspective, namely the societal relationship perspective (Sen 2010:245; Van der Walt \& Potgieter 2012:226). The educationist has to decide about the (pre-theoretical) lifeand worldview perspective from which to approach societal relationship aspects of the discipline problem such as the social context, the nature and role of school, family and society, all the various relationships mentioned during the 
discussion of the research results, the place and role of the teacher and other educators, their knowledge of the problem, their style and manner of approaching it, the notions of: 'an inclusive school approach' and of 'universal school support', 'the supportive teacher', 'the teacher's pivotal position in the problem', 'the problems of educator abuse', 'school difficulties', 'conflicting relationships', 'inconsistency and unrealistic expectations', and so on. The educationist confronted with a discipline problem should develop not only a pertinent societal relationship theory, but also one about the life- and worldview perspective in which such a societal relationship theory should be rooted. In this case, again, if the educator approaches the problem of indiscipline in her or his school from a biblical societal relationship perspective, she or he will see the school as a societal relationship that is, on the one hand, independent of family, church, state and society, but - on the other hand - as closely connected to them all because of the shared membership of all concerned. While she or he will recognise the necessity of tackling the task of indiscipline in the school based on typical school rules, regulations and ethical codes of conduct (Colson \& Pearson 2001:24), she or he will also recognise the need to liaise with all the other societal relationships to which she or he and her or his pupils are party. She or he will therefore liaise closely with the parental homes, with society in general, with the churches to which the learners belong, with public officials as representatives of the state, and so on. By following such a comprehensive policy, she or he would attempt to eradicate the problem on a broad front (Colson \& Pearson 2001:184).

The discussion of the first three perspectives has already pointed in the direction of the fourth, namely that the educationist has to decide on which pedagogical theory to base any interventions aimed at eradicating the discipline problem (De Botton 2012:159). The place and role of education cannot be overlooked; the research results repeatedly refer to the educational roles of the various role players, the importance of an appropriate educational setting, the place and role of values in the educational process, and so on. Education as practice and as theory is always based on some or other life- and worldview perspective; the educationist has therefore to decide on such a perspective: will it be a scripturally founded perspective, or should pedagogical interventions be based on some other life- and worldview? As Peck (2006:240) observes, the word 'education' is derived from the Latin educare, literally translated as: 'to bring out of' or, 'to lead forth'. In a biblical context, this means that the child should be brought out of or led out of a state ignorance about his or her previous sinful state and about the world around him or her, towards a state of repentance and being more knowledgeable about the world as God's creation. The child should also be brought out of ignorance about his or her calling to subject, and rule responsibly over God's creation as his steward towards a proper understanding of what it means to be his steward in this world (for a detailed discussion of the process of 'shepherding the child's heart', see Tripp 2005, and Tripp \& Tripp 2008).

In the fifth and final place, the educationist faced with a discipline problem should decide about the theoretical

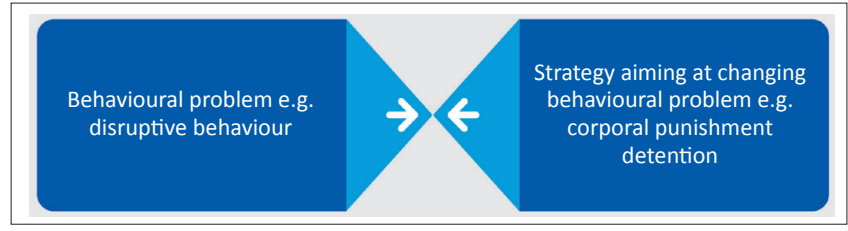

FIGURE 1: The conventional way in which researchers and scholars view learnerdiscipline problems.

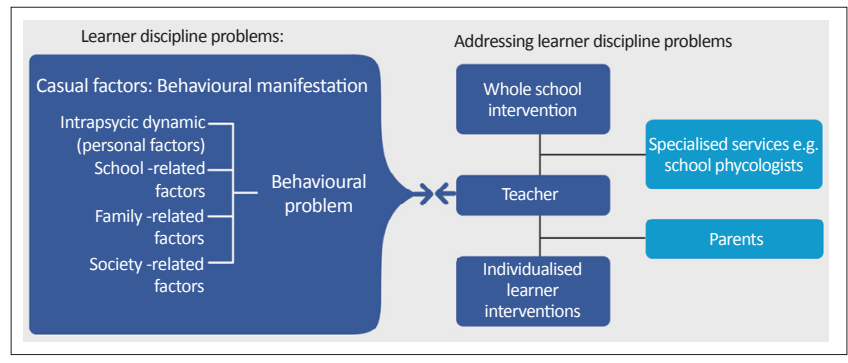

FIGURE 2: Proposed comprehensive, integrated way of viewing and addressing learner discipline problems.

vantage point as well as the supra-rational approach or orientation (Strauss 2009:631) from which to attack the problem. The research results have identified a few such perspectives: the medical or clinical approach, a holistic and comprehensive approach, the psychiatric approach, the holistic-eco-systemic approach, a psycho-social approach, a multi-domain approach, a family-centred approach, a multisource approach, and so on. Every one of these approaches is based on a number of pre-theoretical suppositions and convictions, and these have to be closely examined to see which would be most appropriate in the light of the anthropology, societal relationship theory and pedagogical theory of the educationist. All of these perspectives should be in close alignment as far as their theoretical and pretheoretical foundations are concerned to ensure a total and effective strategy for addressing the discipline problem (Coletto 2008:461). Space constraints do not allow a detailed discussion of such an alignment. Suffice it again to merely state that all five of the perspectives discussed here should be based on or founded in the same pre-theoretical (i.e. philosophical and/or life- and worldview) and theoretical (i.e. scientific) foundations for any interventions based on them to be appropriate and effective.

\section{Conclusion}

The traditional approach to learner-discipline problems versus the thesis presented in this research can be summarised as in respectively Figure 1 and Figure 2.

Rather than focusing on the behavioural outcome of the learner with discipline problems, it is more meaningful and responsible to take a view that includes the intrapsychic and psycho-social (family, school and society-setting) situation of the child as the causal antecedents of discipline problems into account, and to devise a strategy addressing learner discipline problems, which does not only encompass these root causes, but which involves the school, professional counsellor services, and above all, the teacher in the role of much more than a mere behaviour manager. One reason is 
that the behavioural approach is a severely reductionistic and artificial way of looking at learner-discipline problems. Another reason is that it inevitably mistakes the symptoms for the disease, which is unlikely to give rise to a strategy which will permanently address those problems. The notion of 'more meaningful and responsible' can be interpreted in various ways, it is argued, on the basis of the life- and worldview of the educationist. A few brief excursions into a biblical foundational approach to the problem illustrate how the problem could be tackled from a Christian lifeview perspective.

\section{Acknowledgements Competing interests}

The authors declare that they have no financial or personal relationship(s) that may have inappropriately influenced them in writing this article.

\section{Authors' contributions}

E.E.K. (University of Crete) and C.C.W. (North-West University) contributed equally to the writing of this article.

\section{References}

Ainscow, M., Booth, T., Dyson, A., Farrell, P., Frankham, J. Gallannaugh et al. 2006 Traumatic relationships and serious mental disorders, John Wiley \& Sons Inc., Chichester.

Biemond, M., Van der Walt, J.L. \& Wolhuter, C.C., 2010, 'Dissiplineverbetering door omvorming van de klas tot een morele gemeenschap' [Discipline improvement by transforming the classroom into a moral community], Tydskrif vir Christelike Wetenskap 46(1), 55-83.

Blanchard, F., Casagrance, E. \& McCulloch, P., 1994, Echec scolaire: Nouvelles perspectives systémiques, ESF, Paris.

Bloomquist, M.L. \& Schnell, S.V., 2002, Helping children with aggressive and conduct problems: Best practices for interventions, Guilford Publications Inc., New York. problems: Best practic
PMCid:PMC379132

Boxer, P. \& Frick, P.J., 2008, 'Treating conduct problems, aggression, and antisocial behavior in children and adolescents: An integrated view', in R.G. Steele, D. Elkin $\&$ M.C. Roberts (eds.), Handbook of evidence-based therapies for children and \& M.C. Roberts (eds.), Handbook of evidence-based therapies for children and
adolescents, pp. 241-260, Springer, New York. http://dx.doi.org/10.1007/978-0adolescents, pp.

Brehm, K. \& Doll, B., 2009, 'Building resilience in schools. A focus on population-based prevention', in R.W. Christner \& R.B. Mennuti (eds.), School-based mental health: A practitioner's guide to comparative perspectives, pp. 55-86, Routledge, New A practi
York.

Campbell, S., 2002, Behavior problems in preschool children: Clinical and developmental issues, Guilford Publications Inc., New York.

Coletto, R., 2008, "When "paradigms" differ: Scientific communication between scepticism and hope in recent philosophy of science', Koers - Bulletin for Christian Scholarship 73(3), 445-467.

Colson, C. \& Pearson, N., 2001, The Christian in today's culture, Tyndale House Publishers, Wheaton.

De Botton, A., 2012, Religion for atheists, Hamish Hamilton, London.

Dettmer, P., Thurston, L.P. \& Dyck, N.J., 2005, Consultation, collaboration and teamwork for students with special needs, 5th edn., Allyn and Bosch, Boston.

Dinkmeyer, D. Jr \& Carlson, J., 2006, Consultation: Creating school-based interventions, Routledge, New York.

Dishon, T.J. \& Patterson, G.R., 2006, 'The development and ecology of antisocial behaviour', in D. Ciccheti \& D. Cohen (eds.), Developmental psychopathology: Risk, disorder and adaptation, vol. 3, pp. 503-541, John Wiley \& Sons Inc., New York.

Dodge, K.A., 2000, 'Conduct disorders', in A.J. Sameroff, M. Lewis \& S.M. Miller (eds.), Handbook of developmental psychopathology, 2nd edn., pp. 447-463, Klewer Academic/Plenum Publishers, New York.

Dodge, K.A. \& Pettit, G.S., 2003, 'A biopsychosocial model of the development of chronic conduct problems in adolescence', Developmental Psychology 39(2), 349-371. http://dx.doi.org/10.1037/0012-1649.39.2.349

Fell, P. 2002, 'Overcoming barriers to successful support: an examination of issues for teachers and support workers', in P. Gray (ed.), Working with emotions: Responding to the challenge of difficult pupil behaviour in schools, pp. 49-59, Responding to the challenge
Routledge/Falmer, London.
Fraser, M.W., 2004, 'The ecology of childhood: A multisystemic perspective', in M.W. Fraser (ed.), Risk and resilience in childhood: An ecological perspective, pp. 1-12, NAWS Press, Washington DC.

Fraser, M.W., Kirby, L.D. \& Smolowski, P.R., 2004, 'Risk and resilience in childhood', in M.W. Fraser (ed.), Risk and resilience in childhood: An ecological perspective, pp. 13-66, NAWS Press, Washington DC. PMid:15165289

Frick, J.P., 2006, 'Developmental pathways to conduct disorder', Child and Adolescent Psychiatric Clinics of North America 15(2), 311-331. http://dx.doi.org/10.1016/j. chc.2005.11.003

Greenberg, M., Weissberg, R., O'Brien, M., Zins, J., Fredericks, L. \& Resnik, H., 2003 'Enhancing school-based prevention and youth development through coordinated social, emotional and academic learning', American Psychologist 58(6/7), 466474. http://dx.doi.org/10.1037/0003-066X.58.6-7.466, PMid:12971193

Hatzichristou, C., Lykisajou, K., Lampropoulou, A. \& Dimitropoulou, P., 2010 'Promoting the well-being of school communities: A systematic approach', in B. Doll, W. Pfohl \& J. Yoon (eds.), Handbook of youth prevention science, pp. 255274, Routledge, New York.

Henggeler, S.W., Schoenwald, S.K., Borduin, C.M., Rowland, M.D. \& Cunningham, P.B. (eds.), 1998, Multisystemic treatment of antisocial behavior in children and adolescents, Guilford Publications Inc., New York. PMid:9641243

Julian, L., 2002, God is my CEO, Adams Media, Avon.

Kauffman, J.M., 2001, Characteristics of emotional and behavioral disorders of children and youth, 7th edn., Merill Prentice Hall, Columbus.

Kourkoutas, E., 2008, 'Victimization in childhood: Holistic interventions and school inclusion of children victims of violence and social exclusions', in E. Kourkoutas \& J.P. Chartier (eds.), Children and adolescents with psychosocial and learning disorders: Intervention strategies, pp. 303-348, Topos, Athens.

Kourkoutas, E.E., 2012, Behavioral disorders in children: Ecosystemic psychodynamic interventions with the family in school context, Nova, New York. PMCid:PMC3322126

Kourkoutas, E. \& Raul Xavier, M., 2010, 'Counseling children at risk in a resilient contextual perspective: A paradigmatic shift of school psychologists' role in inclusive education', Social and Behavioural Science 5, 1210-1219.

Kourkoutas, E., Georgiadi, M. \& Hadzaki, M., 2011, 'Teachers' perceptions of pupils' social dysfunctions: A combined qualitative and quantitative approach', Social and Behavioral Sciences 15, 3870-3880.

Lategan, L.O.K., 2010, "n Raamwerk vir intellektuele vakmanskap - 'n Filosofiese benadering' [A framework for intellectual craftsmanship - A philosophical approach], Journal for Christian Scholarship 46(3/4), 143-156.

Lunt, I. \& Norwich, B., 2009, 'Inclusive and effective schools: Challenges and tensions', in P. Hick, R. Kershner \& P. Farrell (eds.), Psychology for inclusive education: New directions in theory and practice, pp. 96-107, Routledge, Abington.

Mash, E.J. \& Wolfe, D.A., 2010, Abnormal child psychology, Brooks/Cole, Wadworth, Pacific Grove.

Maughan, B., 2001, 'Conduct disorders in context', in J. Hill \& B. Maughan (eds.), Cambridge child and adolescent psychiatry: Conduct disorders in childhood and adolescence, Cambridge University Press, New York.

McEvoy, A. \& Welker, R., 2000, 'Antisocial behaviour, academic failure and school climate: A critical review', Journal of Emotional and Behavioural Disorders 8, 130140. http://dx.doi.org/10.1177/106342660000800301

McMahon, R.J. \& Forehand, R.L., 2003, Helping the noncompliant child: Family-based treatment for oppositional behaviour, 2 nd edn., Guilford Publications Inc., New York.

Miller, A., 2003, Teachers, parents and classroom behaviour: A psychosocial approach, Open University Press, Maidenhead.

Munger, R.L., Donkervoet, A. \& Morse, W.C., 1998, 'The clinical ecological viewpoint', in D.A. Sabatino \& B.L. Brooks (eds.), Contemporary interdisciplinary interventions for children with emotional/behavioural disorders', pp. 323-349, Carolina for children wic Press, Durham.

Nastasi, B., Moore, R.B. \& Varjas, K.M., 2004, School-based mental health services: Creating comprehensive and culturally specific programs, Amercian Psychological Association, Washington, DC. http://dx.doi.org/10.1037/10724-000

Olthuis, J.H., 2012, 'A vision of and for love: Towards a Christian post-postmodern worldview', Koers - Bulletin for Christian Scholarship 77(1). Art \#28, 7 pages. http://dx.doi.org/10.4102/koersv77i.28

Oosthuizen, I.J., Wolhuter, C.C. \& Du Toit, P., 2003, 'Voorkomende of bestraffende maatreëls in Suid-Afrikaanse skole: Watter benadering moet voorkeur geniet?' [Preventive or punitive measures in South African schools: What approach should prevail?], Koers - Bulletin for Christian Scholarship 68(4), 457-479.

Peck, M.S., 2006, The road less travelled, Arrow Books, New York.

Pianta, R.C., 2006, 'Schools, schooling and developmental psychopathology', in D. Cicchetti \& D. Cohen, (eds.), Developmental Psychopathalogy: Volume 1: Theory and method, pp. 494-529, John Wiley \& Sons Inc., Hoboken.

Richman, J.M., Bowen, G.L. \& Wooley, M.E., 2004, 'School failure: An eco-interactional developmental perspective', in M.W. Fraser (ed.), Risk and resilience in childhood: An ecological perspective, pp. 133-160, NAWS Press, Washington, DC

Roeser, R.W. \& Eccles, J.S., 2000, 'Schooling and mental health', in A.J. Sameroff, M. Lewis \& S.M. Miller (eds.), Handbook of developmental psychopathology, 2 nd edn., pp. 135-156, Klewer Academic/Plenum Publishers, New York.

Ross, M.R., Powell, S.R. \& Elias, M., 2004, 'New roles for school psychologists: Addressing the social and emotional learning needs of students', Schoo Psychology Review 31, 43-52. 
Salend, S.J., 2004, Creating inclusive classrooms: Effective and reflective practices for all students, 5th edn., Pearson/Merrill Prentice Hall, Columbus.

Schmidt Neven, R., 2010, Core principles of assessment and therapeutic communication with children, parents and families: Towards the promotion of child and family wellbeing, Routledge, New York.

Sen, A., 2010, The idea of justice, Penguin Books, London.

Sneider, J., Reid, J. \& Patterson, G., 2003, 'A social learning model of child and adolescent behavior', in B.B. Lahey, T.E. Moffit \& A. Caspi (eds.), Causes of conduct disorders and juvenile delinquency, pp. 27-48, Guilford Publications Inc., New York.

Steyn, S.C., Wolhuter, C.C., Oosthuizen, I.J. \& Van der Walt, J.L., 2003, "n Internasionale perspektief op leerderdissipline in skole' [An international perspective on studen discipline in schools], Suid-Afrikaanse Tydskrif vir Opvoedkunde 23(3), 225-232.

Strauss, D.F.M., 2009, Philosophy: Discipline of the disciplines, Paideia Press, Grand Rapids.

Tripp, T., 2005, Shepherding the child's heart, Shepherd Press, Wapwallopen.

Tripp, T. \& Tripp, M., 2008, Instructing a child's heart, Shepherd Press, Wapwallopen.

Urquhart, I., 2009, 'The psychology of inclusion: The emotional dimension', in P. Hick, R. Kershner \& R. Farrell (eds.), Psychology for inclusive education: New directions in theory and practice, pp. 66-77, Routledge, Abingdon.

Van der Walt, J.L., Potgieter, F.J. \& Wolhuter, C.C., 2010, 'Positiewe dissipline in die hande van die opvoeder' [Positive discipline in the hands of the teacher], Tydskrif vir Christelike Wetenskap 46(1), 145-168.

Van der Walt, J .L. \& Potgieter, F.J., 2012, 'Research method in education: The frame by which the picture hangs', International Journal of Multiple Research Approaches 6(3), 220-232. http://dx.doi.org/10.5172/mra.2012.6.3.220
Van der Westhuizen, P.C., Oosthuizen, I. \& Wolhuter, C.C., 2008, 'The relationship between an effective organizational culture and student discipline in a boarding school' Education and Urban Society 40(2), 205-225. http://dx.doi. boarding school', Education and
org/10.1177/0013124507303992

Walker, H.M., Colvin, G. \& Ramsey, K., 1995, Antisocial behavior in school: Strategies and best practices, Brooks/Cole, Pacific Grove.

Weare, K., 2000, Promoting mental, emotional and social health. A whole school approach, Routledge, London.

Weare, K. \& Gray, G., 2003, What works in promoting children's emotional and social competence and well-being?', Department of Education and Skills, London.

Weideman, A., 2010, 'Stability and change: What our theoretical framework accomplishes for us', Journal of Christian Scholarship 46(3/4), 157-171.

Wolhuter, C.C. \& Van Staden, J.G., 2008, 'Bestaan daar 'n dissiplinekrisis in SuidAfrikaanse skole? Belewenis van opvoeders' [Is there a discipline crisis in South African schools? Experience of educators], Tydskrif vir Geesteswetenskappe 48(3) 389-398.

Wolhuter, C.C. \& Van Staden, J.G., 2009, 'Gender differences in South African educators' experience and handling of learner discipline problems at school', Journal of Educational Studies 8(1), 100-110.

Wright, A., 2010, 'Dancing in the fire: A deconstruction of Clive Erricker's postmodern spiritual pedagogy', Religious Education: The Official Journal of the Religious Education Association 96(1), 120-135.

Young, K.R., Marchant, M. \& Wilder, L.K., 2004, 'School-based interventions for students with emotional and behavioural disorders', in P. Allen-Mears \& M.W. Fraser (eds.), Interventions with children and adolescents: An interdisciplinary perspective, pp. 174-204, Pearson, Boston.

Ysseldyke, J. \& Algozzine, B., 2006, Working with families and community agencies to support students with special needs, Corwin Press, Thousand Oakes. 